NBER WORKING PAPER SERIES

\title{
SPECULATIVE ATTACKS ON PEGGED \\ EXCHANGE RATES: AN EMPIRICAL \\ EXPLORATION WITH SPECIAL \\ REFERENCE TO THE EUROPEAN \\ MONETARY SYSTEM
}

Barry Eichengreen

Andrew K. Rose

Charles Wyplosz

Working Paper No. 4898

\section{NATIONAL BUREAU OF ECONOMIC RESEARCH 1050 Massachusetts Avenue \\ Cambridge, MA 02138 \\ October 1994}

We thank Florence Beranger and Lisa Ortiz for research assistance, and Matthew Canzoneri, Robert Cumby, Robert Flood, and Jeffrey Frankel, Peter Garber, Alberto Giovannini, Vittorio Grilli, Assar Lindbeck, Torsten Persson, Jean Pisani-Ferry, Nouriel Roubini, Lars Svensson, Axel Weber, and seminar participants at UC Berkeley, ESSIM, IIES, the French Ministry of Finance, the Kiel Institute for World Economics, and the Conference on the New TransAtlantic Economy for comments. This paper is part of NBER's research programs in International Finance and Macroeconomics and Monetary Economics. Any opinions expressed are those of the authors and not those of the National Bureau of Economic Research.

() 1994 by Barry Eichengreen, Andrew K. Rose and Charles Wyplosz. All rights reserved. Short sections of text, not to exceed two paragraphs, may be quoted without explicit permission provided that full credit, including $\odot$ notice, is given to the source. 


\title{
SPECULATTVE ATTACKS ON PEGGED \\ EXCHANGE RATES: AN EMPIRICAL \\ EXPLORATION WITH SPECIAL \\ REFERENCE TO THE EUROPEAN \\ MONETARY SYSTEM
}

\begin{abstract}
This paper presents an empirical analysis of speculative attacks on pegged exchange rates in 22 countries between 1967 and 1992. We define speculative attacks or crises as large movements in exchange rates, interest rates, and international reserves. We develop stylized facts concerning the univariate behavior of a variety of macroeconomic variables, comparing crises with periods of tranquility. For ERM observations we cannot reject the null hypothesis that there are few significant differences in the behavior of key macroeconomic variables between crises and non-crisis periods. This null can be decisively rejected for non-ERM observations, however. Precisely the opposite pattern is evident in the behavior of actual realignments and changes in exchange rate regimes. We attempt to tie these findings to the theoretical literature on balance of payments crises.
\end{abstract}

Barry Eichengreen

Department of Economics

University of California, Berkeley

603 Evans Hall

Berkeley, CA 94720

and NBER

Charles Wyplosz

INSEAD

Boulevard de Constance

77305 Fontainebleau

FRANCE
Andrew K. Rose

School of Business

University of California, Berkeley

350 Barrows Hall

Berkeley, CA 94720

and NBER 


\section{Introduction}

Epidemiologists study epidemics as a way of understanding the everday transmission of infectious disease. In similar fashion, international economists can study currency crises as a way of understanding the determinants of exchange rates and international capital flows. It is surprising in this light that we do not possess a body of studies that establish stylized facts about the behavior of macroeconomic variables around the time of speculative attacks. Our goal in this paper is to begin the process of identifying such regularities. We ask questions like the following. Are there differences the the behavior of key macroeconomic variables prior to speculative attacks on pegged exchange rates compared to other periods? Does the behavior of these key variables change in the aftermath of speculative attacks? Do answers to these questions differ in the different times and places in which exchange rates are pegged? Do they differ for ERM and non-ERM currencies, in particular?

Our findings are different for the ERM and non-ERM subsamples. For the non-ERM subsample we find significant differences in the behavior of budget deficits, inflation rates, rates of credit growth, and trade balances when comparing periods preceding speculative attacks and control-group observations. These differences are consistent with the predictions of early contributions to the speculative attack literature -- what we call "first-generation" models - like those of Krugman (1979) and Flood and Garber (1984a). ${ }^{\prime}$ For the ERM subsample, in contrast, there is a striking lack of differences. The behavior of reserves and possibly also interest rates differs between periods of crisis and tranquility; this is not surprising, however, since these are two of the variables on whose basis we categorize episodes as speculative crises. But the only other variables whose behavior differs significantly between crises and non-crises in the ERM subsample are money growth and 
inflation, and the direction of their effects is the opposite of those predicted by firstgeneration models. For the ERM subsample, then, key macroeconomic and financial variables to which first-generation crisis models direct attention do not behave as predicted.

An alternative interpretation of ERM crises is based on second-generation models of self-fulfilling speculative attacks and multiple equilibria in foreign exchange markets, in which policy shifts in a more expansionary direction in response to the attack (Flood and Garber 1984b, Obstfeld 1986). For the ERM subsample, we find little evidence of this pattern. Thus, while our findings cast doubt on the relevance of first-generation models for our ERM episodes of speculative crisis, they do not establish that second-generation models of self-fulfilling attacks necessarily fit the facts.

It is important here to note a problem of observational equivalence. ${ }^{2}$ While the absence of differences in monetary and fiscal variables in periods leading up to speculative attacks and other periods is consistent with models of multiple equilibria, it is also consistent with a restrictive class of models with unique equilibria. Models like those of Flood and Garber (1984b) and Obstfeld (1986) generate multiple equilibria and self-fulfilling crises because they assume a contingent policy process in which policy shifts only in the event of an attack. One can also imagine a model in which policy is expected to shift in a more expansionary direction with certainty; the shift is not contingent. Anticipating that eventuality, speculators may attack the currency just before the policy shift is observed. This is a model with a unique equilibrium in which the speculative attack is motivated by imbalances in underlying fundamentals, but those imbalances only become evident after the attack. Thus, our results for the ERM, which fail to detect distinctive behavior on the part 
of key macroeconomic variables in the period leading up to speculative attacks, are still consistent with first-generation models, but only with a restrictive sub-class in which no hint of future policy imbalances is contained in past and current policy. But the fact that we find little evidence of a shift in policy in more expansionary directions in the aftermath of speculative attacks is difficult to reconcile this view.

A final important finding is that the behavior of macroeconomic variables differs significantly around the time of speculative attacks on the one hand and realignments and changes in exchange rate regimes on the other. ERM countries undergoing realignments have significantly higher inflation rates, interest rates, rates of money and credit growth and budget deficits, and their trade balances are significantly weaker. None of these statements is true about the events associated with realignments of non-ERM currencies or with the collapse of the Bretton Woods, Smithsonian, or Narrow Margin regimes of pegged exchange rates.

Our investigation has obvious relevance to current policy concerns. 1992 and 1993 saw a series of speculative attacks on European currencies that drove the Italian lira and the British pound out of the Exchange Rate Mechanism (ERM) of the European Monetary System (EMS) and challenged the viability of the Maastricht blueprint for European Monetary Unification (EMU). There remains considerable dispute over why these crises occurred. One view emphasizes the unsustainable policy stances of weak-currency countries (Dombusch 1993, Committee of Central Bank Governors 1993a,b, Williamson 1993, Goldstein and Mussa 1994). It blames EMS members whose currencies were attacked for courting danger by their pursuit of lax monetary and fiscal policies and by 
failing to adjust their exchange rates in timely fashion. Accommodating policies and excessive wage and price inflation are said to have led to a loss of international competitiveness, a current account deficit, and a profitability squeeze that left overvalued currencies "ripe for the picking." Another view observes that, for several countries concerned, the evidence of lax policies is far from compelling (Eichengreen and Wyplosz 1993, Portes 1993, Rose and Svensson 1993, Obstfeld 1994). Several ERM countries displayed little evidence of excessive inflation, accommodating policies, or mounting competitive difficulties prior to their currency crises. In this view, the speculative attacks which forced them to raise interest rates created incipient macroeconomic imbalances rather than the other way around and more generally increased the cost of defending the prevailing currency pegs. If the first view is correct, then it may be possible to complete Stage II of the transition to monetary union as sketched in the Maastricht Treaty by returning to the narrow bands of the pre-1993 EMS as soon as Europe's recession ends and policy convergence is restored. But if the second one is accurate, efforts to restore narrow bands may prove futile regardless of the current stance of macroeconomic policies.

In addition, the fiftieth anniversary of the Bretton Woods Agreement, combined with dissastisfaction about the performance of freely fluctuating exchange rates, has reinitiated discussion of international monetary reforms intended to enhance exchange rate stability. In periods when foreign exchange markets are tranquil, it has become customary to argue that exchange rates can be pegged within narrow bands if there is sufficient convergence of national macroeconomic policies. In turbulent periods, in contrast, observers display deep skepticism about whether policymakers will be able to resist 
market pressures regardless of the policies they are currently pursuing. In today's world of high capital mobility, in other words, it may not be possible to restore narrow exchange rate bands along the lines of the Bretton Woods System regardless of the stance of macroeconomic policies. Our attempt to understand whether speculative attacks on pegged exchange rates are necessarily prompted by the inadequate convergence of national policies or whether such attacks can occur even in the absence of policy imbalances has obvious relevance to transatlantic blueprints for international monetary reform.

The remainder of the paper is organized as follows. Section II elaborates the altemative theoretical models in more detail. Section III describes the data and procedures used to analyze the empirics of speculative attacks. Section IV enumerates the speculative episodes generated by our procedures and contrasts them with informal discussions of balance-of-payments crises. ${ }^{3}$ We make special reference to ERM members, since their's is the experience around which much recent discussion revolves. Section V reports univariate characterizations of the behavior of key variables around the time of speculative attacks along with comparisons to control groups, and asks whether the attack and nonattack cases are drawn from the same underlying distributions. Section VI draws out the implications of this empirical work for efforts to interpret speculative attacks in terms of theoretical models.

\section{Theoretical Models. Empirical Implications}

\section{A. A Review of the Literature}

The first generation of balance-of-payments crisis models spawned a large 
literature that is difficult to catalog comprehensively. Our selective survey focuses on contributions with empirical implications.

Krugman's seminal article assumed that an exogenous government budget deficit lay at the root of the balance-of-payments crisis. Excessively expansionary fiscal policy (or, equivalently, in Krugman's otherwise stationary economy, any budget deficit) is financed by issuing domestic credit. The authorities announce that they are prepared to peg the exchange rate until reserves reach a specified lower bound (for present purposes, zero), at which point they shift to floating. With the government pegging the relative rate of return on domestic- and foreign-currency-denominated assets (in Krugman's model, the exchange rate), investors wish to hold domestic and foreign assets in fixed proportions. They rebalance their portfolios by exchanging some of the additional domestic assets for foreign exchange reserves of the central bank. Since they exchange only a portion of the incremental supply (portfolio proportions remaining constant), the shadow exchange rate, which will prevail in the event that the pegging policy is abandoned, depreciates gradually over time. ${ }^{4}$ When it first equals the current exchange rate, investors attack the peg, depleting the authorities' remaining reserves, for to do otherwise would make available arbitrage profits and imply market inefficiency.

The empirical implication of the model, then, is that one should observe expansionary fiscal and monetary policies prior to speculative attacks. Those policies should be accompanied by a gradual decline in international reserves over an extended period.

While Krugman assumes purchasing power parity, it is straightforward to extend 
his model to a semi-small country setting so that a shift to more expansionary fiscal policies increases the demand for domestic goods, driving up their price and leading to real exchange rate appreciation in the period leading up to the attack. Goldberg (1988), for example, relaxed the purchasing power parity assumption maintained by Krugman and Flood and Garber (1984a). If it is assumed that domestic prices adjust only gradually in response to excess demand, they begin rising as soon as agents recognize that the exchange rate will be changed subsequently. The stickier prices, the longer the period prior to the collapse over which real appreciation will be observed.

In models with forward-looking wage contracts (Willman 1988), anticipated future price increases due to currency depreciation affect current wages. As a result, wages should start rising before the attack occurs. While the real interest rate falls as the price level rises, stimulating output, the real exchange rate strengthens, shifting demand toward imports and depressing output. If output is demand determined -- it depends positively on the real exchange rate but negatively on the real interest rate -- then the behavior of output in the period leading up to the crisis is theoretically ambiguous. If the trade balance depends negatively on the real exchange rate (as domestic prices rise, demand shifts toward foreign goods) and negatively on output, the deficit should grow in the period leading up to an attack unless a sufficiently large fall in output is observed.

Other research has focused on modifying Krugman's assumptions regarding the money supply process, the post-attack regime, and the degree of capital mobility. In many of the successful attacks we analyze below, countries did not permanently shift to floating but instead re-pegged the exchange rate at a depreciated level, sometimes 
following a limited period of floating. Wyplosz (1986) analyzes devaluations in the presence of capital controls which limit the degree of capital mobility. The more stringent the controls, the longer the pre-attack period over which the standard correlates of speculative crises -- fiscal deficits, domestic credit creation, real appreciation and trade deficits -- will persist. With sufficiently stringent controls, collapses of the peg can be averted; devaluations from one peg to another become possible. With permeable controls, crises are still possible: Obstfeld (1984) shows that crises occur earlier the larger the anticipated devaluation.

Flood and Garber (1984a) introduce uncertainty about the rate of domestic credit creation. In their discrete-time formulation, unanticipated increases in domestic credit can cause the shadow exchange rate to exceed the pegged rate temporarily. Now speculators attack the peg as soon as this situation makes available arbitrage profits. But as domestic credit grows, an attack becomes increasingly likely, widening the differential between domestic and foreign interest rates. This should be accompanied by a growing forward discount on the domestic currency. Finally, the greater the uncertainty about the central bank's credit policy, the faster reserves should be depleted. The larger the variance of the process governing domestic credit creation, the greater the probability of a regime shift, so that reserve losses exceed increases in domestic credit (Claessens 1991).

To recapitulate, variants of the Krugman-Flood-Garber model have strong implications for the behavior of macroeconomic and financial variables in the period leading up to a crisis. They predict that speculative attacks on pegged exchange rates should be preceded by growing budget deficits and accelerating rates of monetization or 
comparatively fast money growth, and rising wages and prices. Real exchange rates should become increasingly overvalued, and trade deficits should widen. International reserves should decline, domestic interest rates should rise, and forward exchange rates should weaken before the crisis occurs.

The second generation of speculative attack models has different empirical implications. Flood and Garber (1984b) and Obstfeld (1986) were first to formalize the possibility of self-fulfilling speculative attacks. In their models, multiple equilibria exist in the foreign exchange market because of the contingent nature of the authorities' policy rule. In the absence of an attack, monetary and fiscal policies are in balance, and nothing prevents the indefinite maintenance of the currently prevailing currency peg. There is no reason to anticipate the empirical trends described in the preceding paragraph in the period leading up to the attack. If and only if attacked, however, the authorities switch to more accommodating policies consistent with a lower level for the exchange rate. $^{6}$ In this setting, speculative attacks can be self-fulfilling. But there is no reason to anticipate adverse trends in monetary and fiscal policies, wages and prices, reserves or the trade balance prior to the attack. That this is more than a purely theoretical possibility is suggested by the following comment by a well-known market participant.

"A change in the exchange rate has the capacity to affect the so-called fundamentals which are supposed to determine exchange rates, such as the rate of inflation in the countries concerned; so that any divergence from a theoretical equilibrium has the capacity to validate itself. This self validating capacity 
encourages trend-following speculation, and trend-following speculation generates divergences from whatever may be considered the theoretical equilibrium. The circular reasoning is complete. ${ }^{\text {7 }}$

Early second-generation models were predicated on the ad hoc assumption of a contingent policy rule. Subsequent contributions derived the policy process from the optimizing behavior of governments. Ozkan and Sutherland (1994) postulated a tradeoff between the interest rate and the level of unemployment, where the interest rate depended on the exogenously given foreign rate and the exchange rate regime. They showed that high and rising unemployment might lead the government to abandon the peg, anticipations of which could lead to an immediate attack. It is easy to see how this model can generate self-fulfilling attacks: if defense against an attack requires the authorities to raise interest rates relative to world levels and their action further exacerbates unemployment, multiple equilibria can arise. ${ }^{8}$ This formulation implies rising unemployment in the period leading up to the attack, unlike the Willman version of Krugman's model, where the direction of pre-attack output and unemployment trends is ambiguous. Like the Krugman model augmented by risk premia, it predicts rising interest rates.

Thus, simple variants of alternative models generate rather different predictions for the period leading up to an attack. First-generation models predicts expansionary fiscal policies and/or rapid growth of money and credit, increasingly overvalued exchange rates, and a steady drain of reserves. According to second generation models, in contrast, none 
of these patterns will necessarily be visible in the period leading up to the attack. Firstgeneration models do not predict any particular shift in the stance of monetary and fiscal policy following the attack. Most second-generation models, in contrast, suggest that rational self-fulfilling attacks should be followed by a shift in monetary and fiscal policies in a more expansionary direction (although there are exceptions, e.g., Bensaid and Jeanne 1994). ${ }^{9}$

\section{B. Previous Empirical Studies}

There exists only a handful of studies seeking to apply theoretical models of speculative attacks to actual experience with pegged exchange rates. Apparently the first such paper is Blanco and Garber (1986), who used a variant of the Krugman-Flood-Garber model to predict the timing and magnitude of devaluations forced by speculative attacks on the Mexican peso between 1973 and 1982. ${ }^{10}$ Blanco and Garber examine whether the model explains the timing of the devaluations that took place in 1976 and 1982 using a standard money demand function and a first-order autoregressive function for the rate of growth of domestic credit. ${ }^{11}$ International reserves decline as a function of the difference between money supply and money demand, until the critical level is reached at which the speculative attack occurs. They pick the value for that threshold which minimizes the residual sum of squares subject to the constraint that the exchange rate that prevails following the attack is consistent with the post-attack level of domestic credit. Information from the forward market, in conjunction with the assumption of no risk premium, is used to proxy for the expected future exchange rate.

Cumby and van Wijnbergen (1989) take a similar approach to analyzing attacks on 
the Argentine crawling peg of the early 1980s. Where Blanco and Garber combined all money supply and money demand factors into a single variable and fit a stochastic process to it, Cumby and van Wijnbergen estimate different time series processes for the money demand disturbance, the foreign interest rate and domestic credit growth. They treat the level of reserves at which the central bank abandons its currency peg as a stochastic variable. They find that a sharp increase in the growth of domestic credit was the main factor triggering the attack on the currency.

These studies provide only limited information on the extent to which the predictions of the theoretical literature fit the facts. Typically, they are predicated on the predictions of the first-generation (Krugman) model and do not specify an alternative hypothesis or class of models against which those predictions might be contrasted. They focus on a particular country at a point in time, which raises questions -- for those seeking to assess the general explanatory power of the models -- about the representativeness of that episode. Further light on the explanatory power of these theories can be shed only by analyzing a comprehensive set of crisis episodes and contrasting the behavior of the relevant variables in these periods with their behavior during non-crisis episodes.

Studies which do not build directly on the theoretical literature on speculative attacks come closest to what we have in mind. Klein and Marion (1994) use panel data for 16 Latin American countries and Jamaica during the period 1957-1991 to study the determinants of the duration of exchange rate pegs. In their model, the timing of the peg's collapse is determined not by speculative anticipations but by the decisions of an optimizing government which trades off the economic costs of misalignment against the 
political costs of modifying the exchange rate. They justify this emphasis by referring to the prevalence of capital controls which limit the scope for adverse speculation in the countries in question. Nonetheless, their results are broadly consistent with those of the speculative attack literature. They find that the probability of a pegged rate being abandoned increases with the extent of real overvaluation and that it declines with the level of foreign assets. ${ }^{12}$ The limitations of this study are that it focuses on semiindustrialized economies rather than the industrial countries that are our concern here, and that capital controls were prevalent throughout the sample, in contrast to the situation in, say, Europe in the 1990 s.

Similarly, Edwards $(1993,1989)$ examines devaluation episodes in developing countries between 1948 and 1971 and 1962 and 1982, respectively. ${ }^{13}$ The behavior of macroeconomic variables in cases where devaluation occurred is compared with that of a no-devaluation control group. Edwards finds that in the period preceding a devaluation the foreign assets of the central bank typically decline, the real exchange rate becomes overvalued, and fiscal policy becomes excessively expansionary. Besides the fact that Edwards is concerned with developing rather than industrial countries, a limitation of his studies for present purposes is that he compares devaluation and no-devaluation episodes, not attack and non-attack episodes.

\section{The Empirics of Speculative Attacks}

A. Indicators of Speculative Pressure

A first step in any empirical analysis is identifying speculative attacks. We seek to 
do so in ways that minimize the danger of finding patterns purely as a consequence of the manner in which we generate the sample of attack episodes. Were we to limit our attention to successful speculative attacks in which the exchange rate peg or regime was altered (with the currency being devalued or floated), for example, our results would suffer from selectivity bias insofar as some attacks have been warded off by central banks and governments and successful and unsuccessful attacks differ from one another in nonrandom ways.

The obvious solution to this problem is to construct an index of speculative pressure which picks up both successful and unsuccessful attacks. ${ }^{14}$ Ideally, such an index would derive the excess demand for foreign exchange from a model of exchange rate determination (from which the policy actions needed to maintain the exchange rate peg could also be derived). Unfortunately, much research (Meese and Rogoff 1983 is a classic early reference) has underscored the inadequacy of models linking variables like reserve flows and interest rates to the exchange rate. A particular set of weights and fundamentals is only as defensible as the theoretical model used to generate it.

Theory provides a way around this problem only if one is willing to adopt strong assumptions about linkages between exchange rates and macroeconomic fundamentals. To illustrate, consider the model underlying the Girton and Roper (1977) index of exchangemarket pressure. Assuming a textbook money demand function, Girton and Roper specify the percentage change in base money $h$ as a function of the percentage change in the price level $p$, the percentage change in real income $y$ and the percentage change in interest rates i. Since base money is the sum of domestic credit $D$ and international reserves $R$, we can 
define $\mathrm{r}=\mathrm{ER} / \mathrm{H}$ and $\mathrm{d}=\mathrm{D} / \mathrm{H}$, where $\mathrm{E}$ is the domestic price of a unit of foreign exchange. Thus,

$$
\left(\mathrm{r}-\mathrm{r}^{*}\right)+\left(\mathrm{d}-\mathrm{d}^{*}\right)=\left(\mathrm{p}-\mathrm{p}^{*}\right)+\beta\left(\mathrm{y}-\mathrm{y}^{*}\right)-\alpha\left(\mathrm{i}-\mathrm{i}^{*}\right)
$$

where asterisks denote the foreign country, and $\beta(\alpha)$ is the income (interest-rate semi-) elasticity for money demand.

Using purchasing power parity to substitute the rate of depreciation for the inflation differential, and rearranging terms, we can derive:

$$
\mathrm{e}+\left(\mathrm{i}-\mathrm{i}^{*}\right)-\left(\mathrm{r}-\mathrm{r}^{*}\right)=\left(\mathrm{d}-\mathrm{d}^{*}\right)-\beta\left(\mathrm{y}-\mathrm{y}^{*}\right)+(1+\alpha)\left(\mathrm{i}-\mathrm{i}^{*}\right)
$$

The left-hand side of (2) is an index of speculative pressure, which says that pressure increases as domestic reserves of foreign exchange decline, as interest rates rise, and as the exchange rate depreciates (e, the $\log$ of the exchange rate, rises). The theoretical underpinnings suggest that speculative pressure should be a parametric function of fundamentals such as the rate of growth of domestic credit, the level of income, and the interest rate differential.

There are obvious problems with this approach. First, even within the confines of the model the weights attached to the three components of the index of speculative pressure are arbitrary, since terms can simply be added to both sides of (2). Thus, even imposing assumptions about what determines the value of the exchange rate does not pin 
down the weights attached to the components of the index or point to a specific list of fundamentals.

In addition, there is the fact that any such formulation is predicated on a model linking fundamentals to the exchange rate, and thereby to variables like interest rates and international reserves that can be employed in its defense. We have utilized a monetary model to illustrate how indices of speculative pressure might be derived. So long as we are unable to build reasonable empirical models linking macroeconomic fundamentals to the exchange rate, however, we will be incapable of using such models to link the exchange rate to instruments like interest rates and reserves that can be used to defend it or to derive weights to be attached to the components of an index of speculative pressure in a defensible way. To avoid predicating our analysis on a particular model of exchange rate determination, we consider a number of different weighting schemes in the analysis that follows. ${ }^{15}$

A further problem with measuring speculative pressure using linear combinations of exchange rate, reserve, and interest rate changes is created by the fact that, in our sample of countries and periods at least, the conditional volatility of percentage changes in reserves (scaled by the monetary base) is several times the conditional volatility of the percentage change in the exchange rate, which is several times the percentage change in the interest differential. Movements in an unweighted average are therefore heavily driven by reserve movements rather than, say, actual realignments. An intuitive if arbitrary approach is therefore to weight the three components of the index so that their conditional volatilities are equal. ${ }^{16}$ This is the measure we consider below. We conduct 
sensitivity analysis in order to gauge how much different weighting schemes matter.

B. Data

We assembled monthly data from 1967 through 1992 for twenty-two (mostly OECD) countries. The countries were chosen on the basis of data availability and include (in order of IMF country number) the USA, UK, Austria, Belgium, Denmark, France, Italy, Netherlands, Norway, Sweden, Switzerland, Canada, Japan, Finland, Greece, Ireland, Portugal, Spain, Australia, South Africa, India, and Korea, along with our center country, Germany. The data are drawn from the cd-rom version of International Financial Statistics. We compute changes in the exchange rate relative to the DM and changes in interest rates and international reserves relative to those of Germany. ${ }^{17}$

We use the following variables: short-term money market interest rates (IFS line 60b), international reserves (line 11) corrected for intemational liabilities (line 16c) wherever possible, the ratio of the central government budget position (line 80 ) to nominal GDP (typically line 99a), the real effective exchange rate as measured by normalized unit labor costs (line reu, available since 1975 only), the ratio of exports (line 70) to imports (line 71) expressed as a seven-month centered moving average to eliminate excessive noise, domestic credit (line 32), narrow money (line 34i) normalized for the rate of growth of international reserves, and CPI inflation (line 64). The data have been checked for transcription and other errors and corrected. Virtually all of our variables are transformed by taking differences between domestic and German annualized firstdifferences of natural logarithms.

In interpreting our results, it is important to bear in mind limitations of the data. 
First, published series on international reserves are a very imperfect guide to the magnitude of foreign-exchange-market intervention. Central banks sometimes report only the gross foreign assets of the monetary authorities. Since it is standard operating procedure to arrange for stand-by credits in foreign currency, this is a potentially serious problem. When the authorities intervene, they draw on their credit lines without having to sell any of their reported foreign assets. Even countries which provide data on foreign liabilities omit a number of operations which are typically undertaken during periods of speculative pressure, such as off-balance-sheet transactions like swaps and forward market intervention.

Even when published data are accurate, intervention by foreign central banks can be hard to detect. In the ERM, interventions are compulsory at the margins of the currency grid. It is always the case that two (or more) currencies reach their margins simultaneously; thus, compulsory interventions are undertaken simultaneously by two (or more) central banks. Because we analyze changes in the reserves of each country relative to changes in German reserves and Germany has been the perennial strong-currency country, we are likely to pick up much of this foreign intervention. But intervention undertaken by third countries will not be detected. This would be the case if the Netherlands intervened to support the Italian lira, for example. There is also the problem of attributing Germany's interventions to a particular country. German intervention in support of the Italian lira could produce a large percentage rise in German reserves relative to those of the Netherlands, seemingly signalling an attack on the guilder in a period when Dutch reserves were rising. ${ }^{18}$ Only detailed data on exchange-market 
intervention, which central banks rarely release, would solve this problem.

A further issue is that monthly observations may not be of a sufficiently fine periodicity to identify every speculative attack, especially unsuccessful ones. Pressure against pegged currencies can mount quickly and be repelled through interest-rate increases or foreign-exchange-market intervention within the month. If an attack is launched and repelled in a matter of days, the average behavior of interest rates and international reserves over the month may not reveal the intensity of speculative pressures. ${ }^{19}$

In addition, changes in capital controls may affect the meaning of interest differentials and reserve changes. When controls are in place, the authorities may keep the interest rate on the domestic money market virtually unchanged while defending the parity with sterilized purchases on the foreign exchange market. ${ }^{20}$ The problems this creates for our analysis could be circumvented through the use of offshore interest rates; in practice, these are available for only limited periods and countries, however. An alternative is to use the imperfect data that are available on capital controls to contrast the behavior of interest rates, reserves and other variables in periods when controls were present and absent; we pursue this in Eichengreen, Rose, and Wyplosz (1994).

\section{The Attack Episodes}

We begin our analysis by selecting attack episodes (which we refer to as "crises"). Initially, we weigh the components of our index so as to equalize the conditional volatilities of the exchange rate, the interest differential and reserves; we then examine 
outliers which are two or more standard deviations above the sample mean for this index. Sometimes two (or more) outliers occur close together. To avoid measuring the same crisis twice (or more), we exclude second (and subsequent) observations which occur within given proximity to the first crisis (our window width is typically plus and minus six months).

A number of prominent pegged exchange rate crises, such as the September 1992 ERM attacks, show up in our initial list of crises. However, the list is dominated not by exchange-rate realignments under the provisions of the EMS, the European Snake or the Bretton Woods System but by large monthly movements in floating exchange rates. This points to an interesting fact about exchange rate behavior: movements in exchange rates that take place in the wake of speculative attacks are often not significantly larger than the month-to-month movements that can occur in periods of floating. Unconditional exchange rate volatility varies systematically between floating and pegged-but-adjustable exchange rate regimes, in other words; pegged rates exhibit occasional spikes of volatility which do not compensate for the typical periods of tranquility, since comparable spikes occur during floating regimes. ${ }^{21}$

One might argue that these large movements in exchange rates and interest differentials between countries with floating currencies should be classified as speculative attacks. If the governments concerned are engaged in a dirty float or are attempting to maintain a tacit crawling peg, a large movement in the rate beyond the limits of the implicit band might properly be regarded as a consequence of an attack. ${ }^{22}$ For other periods and currencies, however, such as the dollar in the first half of the 1980s, when the 
exchange rate was essentially allowed to float freely, these episodes do not reflect speculative attacks in the sense implied by either the first or second generation of theoretical models. ${ }^{23}$ Since most of the literature on speculative attacks and the interest of most observers has focused on attacks on pegged currencies, we limit our sample to countries and periods when currencies were pegged under the provisions of the Bretton Woods System, the Snake, the EMS and other explicitly-announced exchange rate bands. $^{24}$

Even when we limit the sample in this way, several prominent realignments of pegged exchange rates do not appear in the list of "crises." This directs one to a second important fact: that not all realignments involve speculative crises. It underscores our point that exchange rate changes and speculative attacks are not the same.

To assess the plausibility of the attack episodes or "crises" generated by our procedure and their sensitivity to different weights, we limited the sample to ERM countries starting in 1979 , since this pegged-rate regime has been the subject of intense study. The list of months and countries that we identify as "crises" is arrayed in descending order of magnitude in Table 1. For each, we report the value of the crisis index, the percentage change in the exchange rate (the domestic currency price of the DM), the percentage change in the interest differential, and the percentage change in relative reserves.

Three features of the table stand out. First, there is a correlation between the dates of ERM realignments and our list of speculative attacks on ERM currencies. At the head of the list are crises in a number of countries associated with the Fall 1992 ERM 
crisis. January 1987, which appears on the list for three countries, was the date of a major ERM realignment. We also identify episodes in which no realignment took place. $^{25}$ Most of these are readily interpretable: to cite two recent examples, they include pressure on the British pound in August 1992 and speculation against the French franc in the Fall of 1992 following the Scandinavian devaluations. Second, the most severe crises, as measured by our index, tend to be recent, underscoring the role of the growth of the foreign exchange market and the removal of capital controls in augmenting speculative capital flows. ${ }^{26}$ Third, changes in exchange rates, interest rates and reserves are correlated in the manner predicted by theory and intuition: interest rate increases and currency depreciation are positively correlated with one another, while both are negatively correlated with reserves. ${ }^{27.28}$

V. Results

\section{A. Characteristics of Speculative Crises}

We now compare the behavior of macroeconomic and financial variables around the time of our "crises" with a control group of non-crisis cases. We construct the control group as all observations that remain (with six-month exclusion windows on either side) once the crises are removed. ${ }^{29}$

The data are displayed in Figures 1 and $2 .^{30}$ The four top left panels of Figure 1, for example, display the behavior of fiscal deficits (as a percent of GDP). They present histograms for ERM crises, ERM non-crises (tranquil periods), non-ERM crises, and nonERM non-crises. ${ }^{31}$ Figure 1 also presents histograms for the smoothed ratio of exports 
to imports, the inflation differential, and the real exchange rate relative to its 1985 level. Figure 2 contains comparable graphs for differential credit growth, differential money growth, the interest differential, and differential reserve growth. ${ }^{32}$

Differences are most apparent to the naked eye in the case of international reserves. This is not surprising, since their behavior was one of the criteria used to differentiate crises from non-crises. Note, however, that a crisis can still take place without a loss of reserves (due to a large change in the exchange rate or the interest differential), and that a large change in reserves can take place without necessarily classifying an observation as an event. ${ }^{33}$ A number of other differences are also apparent in the histograms. Non-ERM trade ratios and interest differentials appear to have different distributions in crisis and non-crisis periods, for example.

The distributions displayed in Figures 1 and 2 can be more systematically compared using statistical techniques. Comparisons between the crisis and non-crisis distributions are tabulated in Table $2 .^{34}$ We report two non-parametric tests: the twosample Kolmogorov-Smimov test for equality of the distribution functions (which examines the entire distribution), and the Kruskal-Wallis test for the equality of populations (which focuses more on sample medians). We also report the traditional t-test for equality of first-moments (without assuming equal variances).

In Table 2 the null hypothesis is that there is no difference in the distributions of our variables in crisis and non-crisis periods. The statistics tabulated are probabilities computed under the null, so that small numbers lead one to reject the hypothesis of equality of distributions, i.e., to find evidence that the variables appear to behave 
differently in periods of crisis and tranquility.

According to the Kolmogorov-Smirnov test, for the non-ERM sample we are able to reject the null of equality for the budget deficit, the inflation differential, the ratio of exports to imports, reserve growth and possibly differential credit growth. Results are comparable for the Kruskal-Wallis test. Only for the real exchange rate, differential money growth, and the interest differential is it impossible to reject the null that the observations are drawn from a common underlying distribution.

The t-tests, in the third column, similarly reject the null of equal means for inflation, the trade balance, credit growth and reserve growth. Most of the differences go in directions consistent with first-generation speculative attack models. Inflation rates are lower, the ratio of exports to imports is higher, and reserve growth is faster in countries not suffering balance-of-payments crises. ${ }^{35}$

The results for the ERM are strikingly different. According to both the Kolmogorov-Smirnov and Kruskal-Wallis tests, we are unable to reject the null of equal distributions for the budget deficit, the real exchange rate, the inflation differential, the trade ratio, and differential credit growth. The results for differential money growth and the interest rate differential are more marginal, while reserves behave quite differently in attacks and non-attack periods --although, to repeat, reserves are one of the variables on the basis of which we categorized the observations. ${ }^{36}$

For the ERM sample we reject the null of equal means for relative rates of reserve growth, relative interest rates, money growth and inflation. The first two results follow from our procedure for distinguishing crises from non-crises. But the signs on the t- 
statistics for inflation and money growth indicate that both variables are larger for noncrises than for crises, rather than smaller as predicted by first-generation models of balance-of-payments crises.

There is a danger of over-interpreting such results and, given the problem of observational equivalence emphasized in the introduction, of spuriously rejecting the predictions of the first-generation models. Nevertheless, the contrast between the ERM and non-ERM samples is striking. The results appear to corroborate some elements of standard first-generation theoretical attack models for non-ERM observations while apparently rejecting the model for the ERM.

As for why these contrasts are so pronounced, we can only offer conjectures. Not even ardent proponents of second-generation models of multiple equilibria and selffulfilling speculative attacks would deny that policy imbalances and competitiveness problems have been at the root of some crises (in the final years of the Bretton Woods System, for example). But second generation models suggest that the scope for selffulfilling attacks is greatest in an environment of high capital mobility and abundant international liquidity. This characterizes the environment of the ERM to a greater extent than predecessors such as the Snake and the Bretton Woods System, which could possibly account for the different patterns we observe.

We undertook a number of experiments as sensitivity analyses; some of these are reported in Table 3. We narrowed the exclusion window from (plus and minus) six to three months without changing our results (we also widened the window to twelve months and obtained similar results). We doubled the weight on reserves in our index of 
speculative pressure which is used to identify crises; again, the results did not vary greatly. Finally, we classified crises using a criterion of two (instead of three) standard deviations above the sample mean; again, the results proved relatively insensitive to the change. ${ }^{37}$

\section{B. Analysis of Realignments and Changes in Exchange Rate Regimes}

In this subsection, instead of using our index of speculative pressure to identify crisis episodes, we look at actual realignments and changes in exchange rate regimes. We dub the latter "events" to distinguish them from "crises."

It turns out that the results hinge critically on whether we compare events with non-events or crises with non-crises. Contrary to the results of Section V.A on crises, the first-generation speculative attack models work relatively well for ERM events but not for non-ERM events. For the latter, there are few significant differences in the behavior of key macroeconomic variables.

Figures 3 and 4 are histograms for event and non-event episodes that correspond to Figure 1 and 2 for crises and non-crises). The histograms reveal substantial differences in the distributions of ERM fiscal ratios between events and non-events. ERM inflation and money growth differentials also appear to be noticeably different.

Table 4 is the analog to Table 2 in that it shows the tests for equality of distributions and for equal means (now across events and non-events rather than crises and non-crises). None of the non-ERM statistics indicate significant differences conventional significance levels. This is true not only of the non-parametric tests for equality of distributions and populations but also of the t-tests for equal means. The opposite is true 
of the ERM observations. Except for the fiscal ratio and the real exchange rate, the test statistics reject the null of equality of distributions across events and non-events. The differences in sample first moments between ERM events and non-events are economically interesting as well. Inflation rates, money and credit growth rates, and interest rates are all higher for events than non-events, while the export/import ratio and reserve growth are lower. These results are quite consistent with standard first-generation models of speculative attacks.

The contrasts between Tables 2 and 4 underscore the fact that some realignments and shifts from pegging to floating take place without speculative attacks, while not all attacks are successful. "Events" and "crises" are different, in other words. The evidence on "events" is broadly supportive of first-generation speculative-attack models but only for the ERM subsample. The evidence on "crises" is also supportive of the first-generation model but more weakly and only for non-ERM observations. This is consistent with the notion that governments historically chose to realign ERM currencies on the basis of standard macroeconomic criteria but that speculators chose to attack ERM currencies for other reasons. ${ }^{38}$

The fact that crises and events are are not the same is corroborated in Table 5. The statistics tabulated there test the null equality of distributions and populations across events and crises for our eight macroeconomic and financial variables. The tests are performed for the ERM subsample, the non-ERM subsample, and the full sample. All the variables except the real exchange rate are distributed differently in crises and events.

We also tested for differences in the distributions of macroeconomic and financial 
variables before and after exchange-market disturbances. We compared their values six months before and six months after both "crises" and "events." As Table 6 shows, there are almost no statistically significant differences in the behavior of our eight variables either for ERM or non-ERM observations.

This result is consistent with simple versions of the first-generation model, which posit that countries are running policies too expansionary to be compatible with indefinite maintenance of the exchange-rate peg but do not specify a change in that policy following the collapse of the peg. It is incompatible, however, with the restrictive subclass of firstgeneration models which predict a deterministic future shift in policy in a more expansionary direction as the factor prompting the crisis. It is also incompatible with models of multiple equilibria which predict a shift towards looser policy following a successful attack.

Thus, taken together with our other results, the analysis in Table 5 points to empirical shortcomings of all existing classes of models of speculative attacks.

\section{Conclusions and Emplications}

We have analyzed the behavior of a range of macroeconomic and financial variables in the periods leading up to speculative attacks on pegged exchange rates. We consider data from official exchange rate pegs in the OECD countries since 1967, including the Bretton Woods System, the Snake of the 1970s, and the European Monetary System. Our results are noticeably different for the ERM and non-ERM subsamples. For the non-ERM subsample we identify significant differences in the behavior of budget 
deficits, inflation, export/import ratios, domestic credit growth, and international reserves in pre-attack and other periods. Only for the real exchange rate, money growth and interest rates is it impossible to reject the null that the observations are drawn from a common underlying distribution. This is consistent with the predictions of first-generation speculative attack models like that of Krugman (1979). For the ERM subsample, in contrast, there is a striking absence of differences between events and other observations. Aside from reserves and interest rates, which are two of the variables on whose basis we categorize episodes as events, we tend to be unable to reject the null of equal distributions for any variable, and where we reject that hypothesis the difference goes in the opposite direction from the predictions of first-generation models. It does not appear, in other words, that the policy imbalances to which first-generation models direct attention are obviously associated with the incidence of speculative attacks on ERM currencies. This absence of significant differences in the ERM subsample is consistent with the predictions of second generation models emphasizing multiple equilibria and self-fulfilling attacks. The high capital mobility and abundant international liquidity of the relatively recent ERM period, which make self-fulfilling attacks relatively easy to launch, may explain this contrast.

When we compare actual realignments and changes in exchange rate regimes with tranquil periods, the results are strikingly different. The first-generation model works well in predicting the behavior of macroeconomic variables for currencies participating in the ERM but not for the non-ERM observations.

Given the limitations of models of exchange rate determination and fundamental 
problems of observational equivalence, it is inevitably difficult to determine whether our findings are more easily reconciled with descendants of the first or second generation of balance-of-payments crisis models. Insofar as the pre-attack behavior of monetary and fiscal variables is at the heart of the distinction between them, we believe that where ERM crises are concerned our findings tend to shift the burden of proof toward the proponents of first-generation models. Admittedly, we also fail to turn up strong evidence favoring second-generation models, since we do not detect significant shifts in macroeconomic variables in the wake of speculative attacks. But however they are inclined to interpret the results, we hope that we have convinced our readers that shedding additional light on these questions requires further empirical analysis of the sort we offer here. 


\section{Table 1: ERM Crises}

ERM Crises

(Ranked in Order of Magnitude of Crisis)

$\begin{array}{lccccc}\text { Country } & \text { Date } & \text { Crisis }^{*} & \phi_{0} \Delta \mathrm{e} & \% \Delta\left(\mathrm{i}-\mathrm{i}^{*}\right) & \% \Delta\left(\mathrm{r}-\mathrm{r}^{*}\right) \\ \text { Ireland } & 1992.11 & 18.7 & -.34 & 2.34 & -33.58 \\ \text { Italy } & 1992.09 & 18.4 & 6.00 & .24 & -133.90 \\ \text { France } & 1992.09 & 14.9 & .21 & .33 & -155.58 \\ \text { Spain } & 1992.09 & 10.6 & 4.68 & .03 & -71.33 \\ \text { Denmark } & 1992.09 & 8.7 & .43 & .15 & -90.36 \\ \text { Ireland } & 1986.08 & 7.8 & 7.41 & .04 & -1.40 \\ \text { Belgium } & 1982.03 & 6.4 & 7.16 & -.13 & -1.20 \\ \text { France } & 1987.01 & 5.1 & 1.46 & .15 & -31.58 \\ \text { Deamark } & 1979.06 & 4.8 & 2.03 & .15 & -21.91 \\ \text { Denmark } & 1987.01 & 4.7 & .37 & .12 & -44.29 \\ \text { France } & 1982.06 & 4.7 & 3.83 & -.03 & -12.87 \\ \text { Denmark } & 1981.03 & 4.7 & 1.77 & .28 & -11.63 \\ \text { Italy } & 1981.10 & 4.6 & 4.87 & .07 & 9.18 \\ \text { UK } & 1992.08 & 4.6 & 1.69 & -.03 & -38.87 \\ \text { Ireland } & 1986.01 & 4.6 & 1.13 & .32 & -14.63 \\ \text { France } & 1981.05 & 4.2 & 1.34 & .27 & -12.53 \\ \text { Belgium } & 1992.09 & 4.2 & .19 & .01 & -49.18 \\ \text { Italy } & 1987.01 & 4.2 & 1.96 & .11 & -18.08 \\ \text { Ireland } & 1982.12 & 4.0 & 2.20 & .28 & 1.41\end{array}$

"Crisis" is defined as Crisis $=\mathscr{K} \Delta \mathrm{e}+7\left[\% \Delta\left(\mathrm{i}-\mathrm{i}^{*}\right)\right]-.08\left[\% \Delta\left(r-r^{*}\right)\right]$, where e denotes the price of $\& D M, i$ is the short interest rate, $r$ is the level of international reserves, and an asterisk denotes German variables. A six-month exclusion window and a one and a half deviation episode delimiter are used to define crises. 
Table 2: Comparing Crises to Non-Crises

$\begin{array}{lllllll} & \text { K-S } & \text { K-W } & \text { t } & \text { K-S } & \text { K-W } & \text { t } \\ \text { Fiscal Ratio } & .00 & .01 & -1.93 & .75 & .78 & 0.12 \\ \text { Real Rate } & .35 & .53 & -0.60 & .45 & .79 & 0.37 \\ \text { Inflation } & .02 & .01 & -2.28 & .20 & .08 & 2.78 \\ \text { X/M } & .00 & .00 & 3.14 & .18 & .13 & -0.91 \\ \text { Credit Growth } & .09 & .07 & 1.99 & .35 & .17 & 0.79 \\ \text { Money Growth } & .12 & .28 & -1.19 & .06 & .03 & 2.65 \\ \text { Interest Rate } & .34 & .37 & -1.20 & .05 & .05 & -1.92 \\ \text { Reserve Growth } & .00 & .07 & 2.32 & .00 & .00 & 3.00\end{array}$

"KS" denotes probability of rejection of null hypothesis (of equality of distribution across crises and non-crises), using the non-parametric Kolomogorov-Smimov test; a low value is inconsistent with the null hypothesis. "K$W^{*}$ denotes probability of rejection of null hypothesis (of equality of distribution across crises and non-crises), using the non-parametric Kruskal-Wallis test. " $t$ " denotes a $t$-test of the null hypothesis of equality of firstmoments across crises and non-crises; a positive number indicates that the sample mean in the absence of crises is higher than the sample mean during crises.

Throughout, a six-month exclusion window and a three-standard deviation event delimiter are used in defining crises. 


\section{Table 3: Robustness Checks for Crises/Non-Crises Comparison}

Three-month Exclusion Window

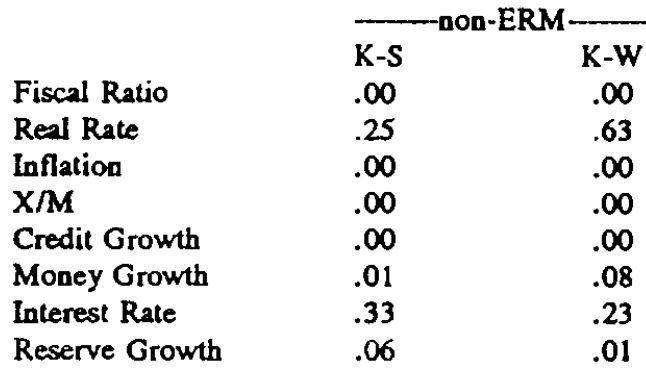

\begin{tabular}{lc}
\hline K-S & K-W \\
\hline 94 & .93 \\
.61 & .79 \\
.22 & .09 \\
.27 & .14 \\
.84 & .52 \\
.07 & .03 \\
.04 & .04 \\
.00 & .00
\end{tabular}

Doubled Weight on Reserves

$\begin{array}{lcc} & \text { K-S } & \text { K-W } \\ \text { Fiscal Ratio } & .00 & .01 \\ \text { Real Rate } & .38 & .56 \\ \text { Inflation } & .01 & .00 \\ \text { X/M } & .00 & .00 \\ \text { Credit Growth } & .03 & .04 \\ \text { Money Growth } & .15 & .32 \\ \text { Interest Rate } & .40 & .66 \\ \text { Reserve Growth } & .02 & .18\end{array}$

\begin{tabular}{lc}
\hline K-S & \\
.23 &.$-W$ \\
.29 & .52 \\
.22 & .14 \\
.59 & .66 \\
.35 & .17 \\
.53 & .25 \\
.03 & .04 \\
.00 & .00
\end{tabular}

A Two-Standard Deviation Event Threshold

\begin{tabular}{|c|c|c|c|c|}
\hline \multicolumn{5}{|c|}{-non-ERM- } \\
\hline & $\mathbf{K}-\mathbf{S}$ & K-W & $\mathbf{K}-\mathbf{S}$ & $\mathbf{K}-\mathbf{W}$ \\
\hline Fiscal Ratio & .00 & .00 & .30 & .29 \\
\hline Real Rate & .30 & .38 & .22 & .36 \\
\hline Inflation & .00 & .00 & .50 & .42 \\
\hline $\mathrm{X} / \mathrm{M}$ & .07 & .07 & .53 & .89 \\
\hline Credit Growth & .71 & .73 & .92 & .89 \\
\hline Money Growth & .04 & .29 & .11 & .08 \\
\hline Interest Rate & .55 & .66 & .05 & .04 \\
\hline Reserve Growth & .16 & .58 & .00 & .00 \\
\hline
\end{tabular}

"K-S" denotes probability of rejection of null hypothesis (of equality of distribution across crises and non-crises), using the non-parametric Kolomogorov-Smimov test. "K-W" denotes probability of rejection of null hypothesis (of equality of distribution across crises and non-crises), using the non-parametric Kruskal-Wallis test. 


\section{Table 4: Comparing Actual Events to Non-Events}

\begin{tabular}{|c|c|c|c|c|c|c|}
\hline & & D $-E R$ & & \multicolumn{3}{|c|}{-ERM- } \\
\hline & K-S & K-W & $t$ & K-S & K-W & t \\
\hline Fiscal Ratio & .47 & .29 & -1.42 & .12 & .04 & 1.94 \\
\hline Real Rate & .27 & .20 & -1.26 & .47 & .39 & -1.17 \\
\hline Inflation & .54 & .55 & -0.46 & .00 & .00 & 4.12 \\
\hline $\mathrm{X} / \mathrm{M}$ & .55 & .60 & -0.60 & .00 & .00 & 3.44 \\
\hline Credit Growth & .08 & .51 & -1.09 & .00 & .00 & -3.92 \\
\hline Money Growth & .71 & .64 & 0.53 & .01 & .00 & -3.58 \\
\hline Interest Rate & .00 & .47 & -0.02 & .00 & .00 & -5.03 \\
\hline Reserve Growth & .00 & .96 & -0.89 & .00 & .02 & 2.42 \\
\hline
\end{tabular}

"K-S" denotes probability of rejection of null hypothesis (of equality of distribution across events and nonevents), using the non-parametric Kolomogorov-Smirnov test. "K-W" denotes probability of rejection of aull hypothesis (of equality of distribution across events and non-events), using the non-parametric Kruskal-Wallis test. " $t$ " denotes $a t$-test of the aull hypothesis of equality of first-moments across events and aon-events.

Throughout, a six-month exclusion window and a three-standard deviation event delimiter are used. Events include: realignments; devaluations; flotations; and fixations.

Table 5: Comparing Events to Crises

\begin{tabular}{|c|c|c|c|c|c|c|}
\hline & \multicolumn{2}{|c|}{ - } & \multicolumn{2}{|c|}{-non-ERM- } & \multirow{2}{*}{$\begin{array}{l}\text { RM-S } \\
\text { K-S }\end{array}$} & \multirow[b]{2}{*}{$\mathbf{K}-\mathbf{W}$} \\
\hline & K-S & $\mathrm{K}-\mathrm{W}$ & $\mathbf{K}-\mathbf{S}$ & $\mathrm{K}-\mathrm{W}$ & & \\
\hline Fiscal Ratio & .00 & .00 & .29 & .27 & .29 & .35 \\
\hline Real Rate & .81 & .98 & .85 & .74 & .56 & .42 \\
\hline Inflation & .00 & .04 & .60 & .60 & .02 & .01 \\
\hline $\mathrm{X} / \mathrm{M}$ & .01 & .01 & .05 & .06 & .02 & .01 \\
\hline Credit Growth & .00 & .00 & .00 & .03 & .24 & .08 \\
\hline Money Growth & .93 & .81 & .25 & .31 & .05 & .02 \\
\hline Interest Rate & .00 & .10 & .01 & .42 & .64 & .86 \\
\hline Reserve Growth & .17 & .98 & .01 & .52 & .11 & .18 \\
\hline
\end{tabular}

"K-S" denotes probability of rejection of aull hypothesis (of equality of distribution across events and crises), using the non-parametric Kolomogorov-Smimov test. "K-W" denotes probability of rejection of aull bypotbesis (of equality of distribution across events and crises), using the non-parametric Kruskal-Wallis test.

Throughout, a six-month exclusion window and a three-standard deviation event delimiter are used. Events include: realignments; devaluations; flotations; and fixations. 


\section{Table 6: Distributions Six Months Before and Six Months After Crises and Events}

\section{Crises}

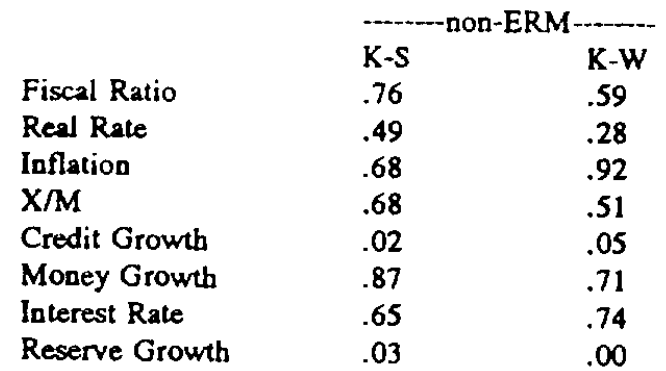

\begin{tabular}{lc}
\hline K-S & K-W \\
.92 & .56 \\
.90 & .56 \\
.31 & .38 \\
.59 & .38 \\
.43 & .32 \\
.79 & .51 \\
.59 & .24 \\
.90 & .56
\end{tabular}

\section{Events}

Fiscal Ratio

Real Rate

Inflation

$\mathrm{X} / \mathrm{M}$

Credit Growth

Money Growth

Interest Rate

Reserve Growth

\begin{tabular}{ll}
\hline K-S & K-W \\
.74 & .69 \\
.99 & .66 \\
.27 & .62 \\
1.0 & .92 \\
.04 & .10 \\
.77 & .62 \\
.04 & .02 \\
.00 & .05
\end{tabular}

\begin{tabular}{lc}
\hline K-S & K-W \\
.56 & .50 \\
.76 & .65 \\
.60 & .68 \\
.32 & .31 \\
.19 & .35 \\
.04 & .02 \\
.12 & .09 \\
.39 & .16
\end{tabular}

"K-S" denotes probability of rejection of null hypothesis (of equality of distributions six months before crises/events to six months after events/crises), using the non-parametric Kolomogorov-Smirnov test. "K-W" denotes probability of rejection of null hypothesis (of equality of distributions six months before events/crises to six months after crises/events), using the non-parametric Kruskal-Wallis test.

Throughout, a six-month exclusion window and a three-standard deviation eveat delimiter are used. 


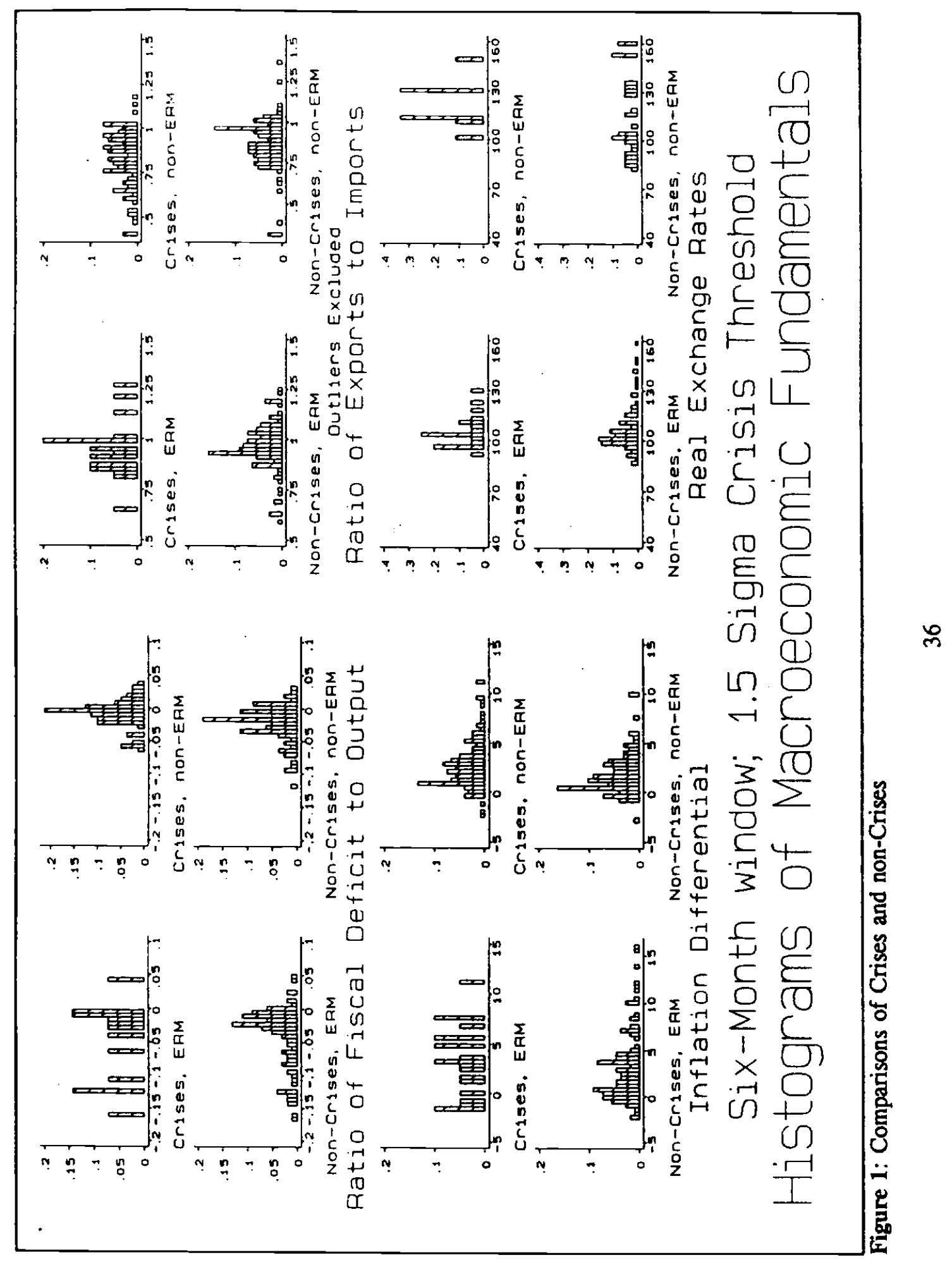




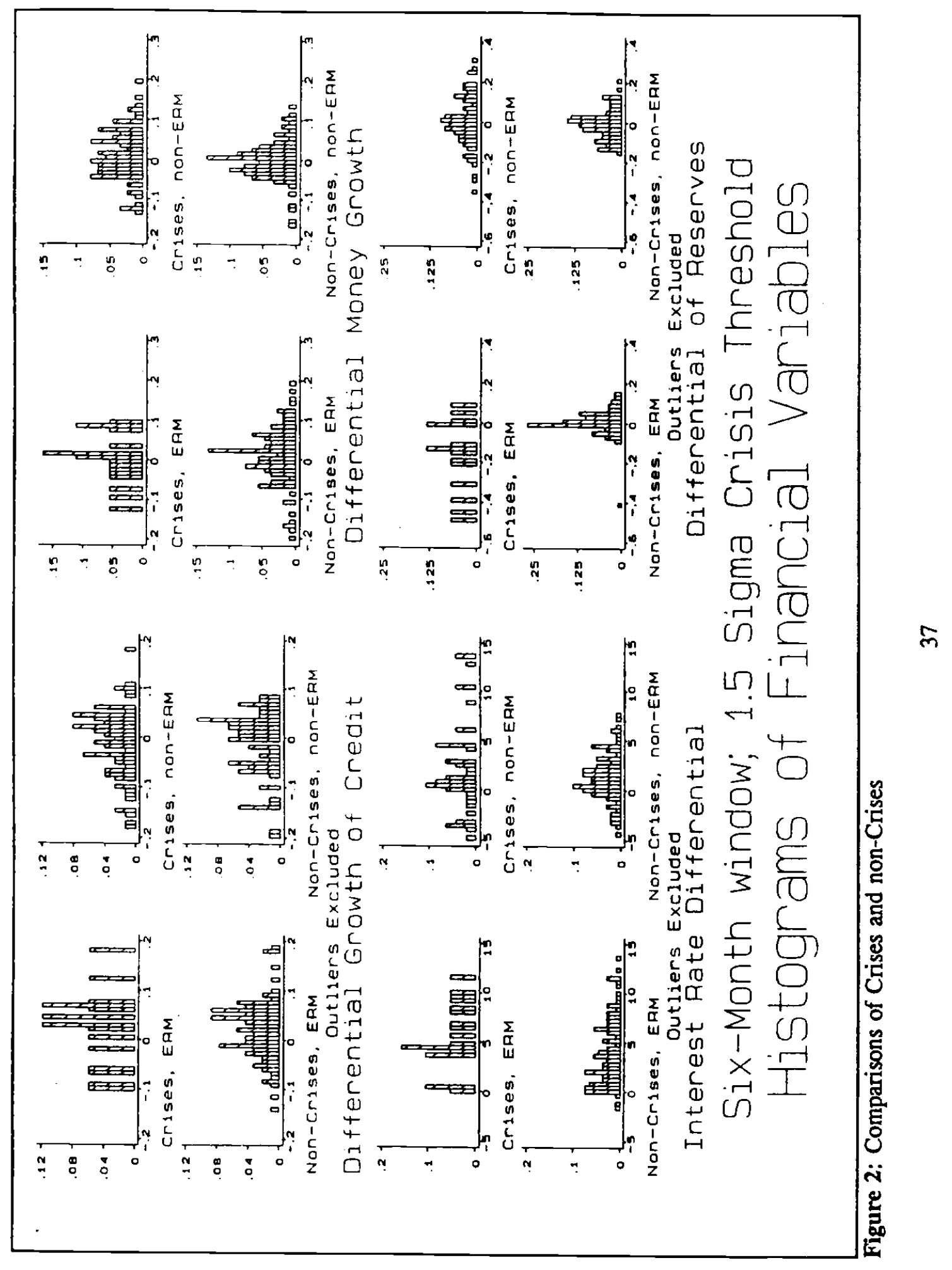




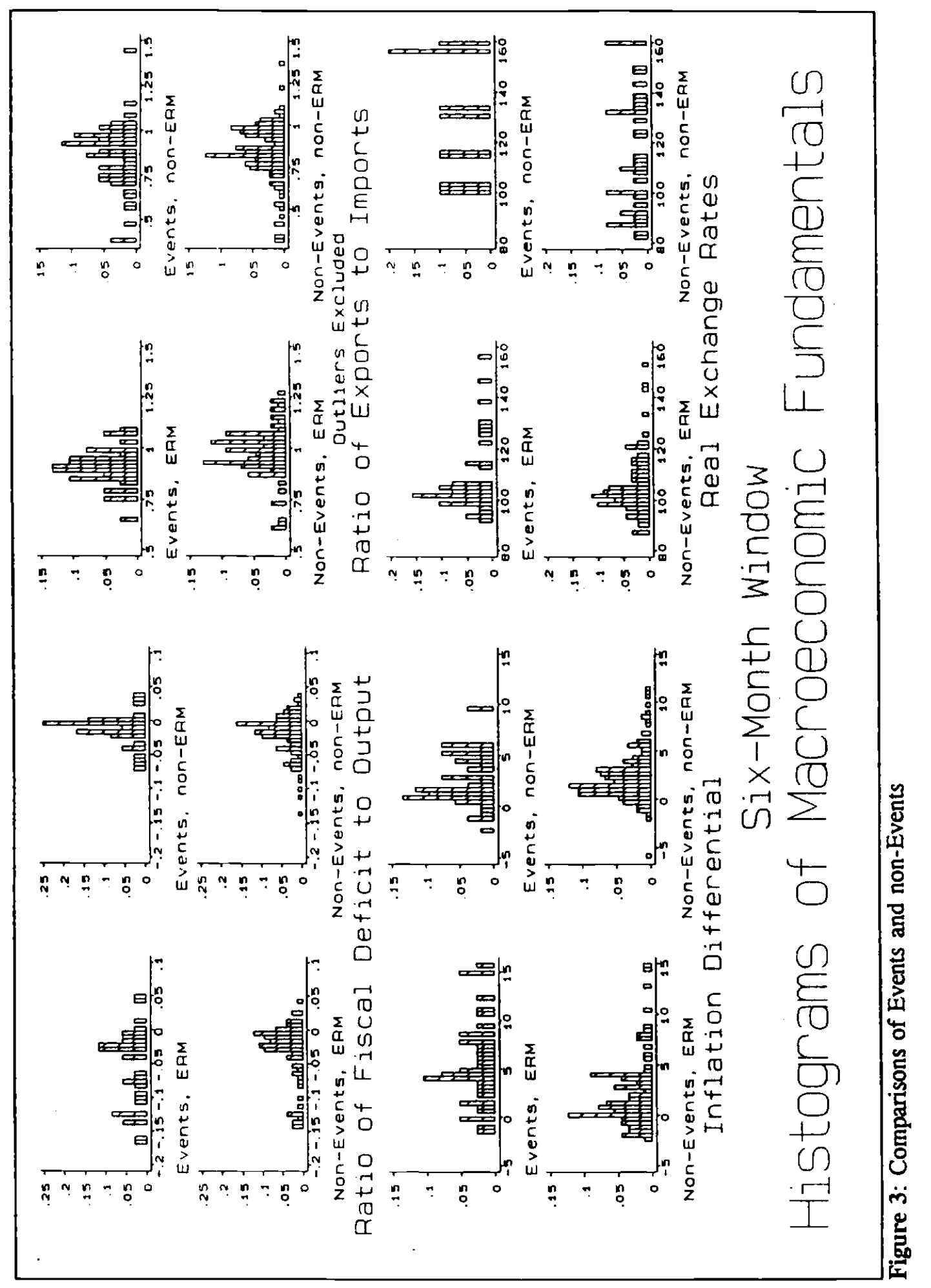




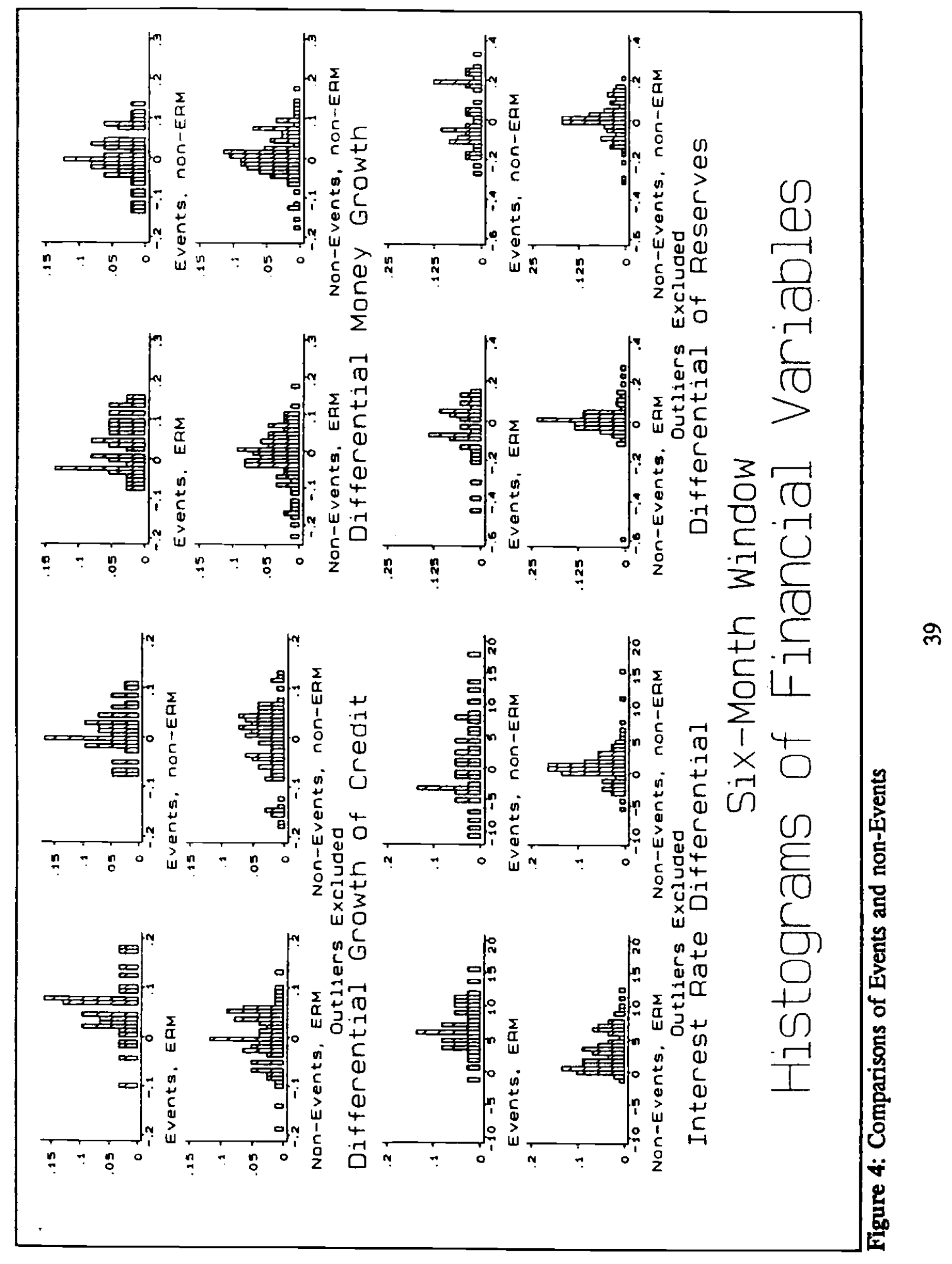




\section{Appendix: The Context of EMS Crises}

One way of gauging the plausibility of our procedure for identifying speculative attacks is to relate the attack episodes identified by the index to historical events. In this appendix we do so for each country-month "crisis" generated by our procedure when the components of our index are weighted to equalize volatilities, the sample is limited to ERM members since 1979, and a one and a half standard deviation threshold is used. We search the financial press for reports of speculative pressure on the currency in the month in question.

\section{June 1979: Denmark}

Germany's support of the DM pushed up the grid against other currencies, adversely affecting the weak members. European central banks were forced to sell DM to keep the Danish krone from falling through the bottom of its band.

\section{March 1981: Denmark}

The Danish economy was suffering a large current account deficit, putting downward pressure on the currency. Also, Italy's realignment and the resulting implications for competitiveness reinforced the weakness of the currency.

\section{May 1981: France}

The franc declined in response to an upward move in U.S. interest rates and nervousness about a possible Socialist victory in the second round of Presidential elections.

\section{October 1981: Italy}

France and Italy devalued, while the DM and the Dutch guilder were realigned upward in the ERM.

\section{March 1982: Belgium}

Suffering high unemployment, a rising budget deficit and a large current account deficit, Belgium devalued by $8.9 \%$.

\section{June 1982: France}

France devalued by $5.75 \%$, pushed in part by the strength of the dollar and waves of speculation against the franc that washed away more than two-thirds of the country's foreign exchange reserves.

December 1982: Ireland

Sterling's weakness raised questions about the stability of the punt.

August 1986: Ireland

Ireland devalued the punt by $8 \%$ in order to encourage exports.

January 1987: Ireland; France; Denmark; Italy 
The 11 th realignment of the EMS was barely complete before speculators began betting on the next one. On January 6th the franc fell to the bottom of the ERM grid, spurred by student riots and public-sector strikes. European finance ministers devalued the Danish krone by $3 \%$ and the Belgian franc by $2 \%$. Italy announced plans to liberalize its exchange controls.

\section{August 1992: United Kingdom}

Reports that Helmut Schlesinger, the Bundesbank's president, had said that he felt that the pound should be devalued triggered heavy selling of sterling.

\section{September 1992: Italy; France; Spain; Denmark; Belgium}

A sliding dollar and anxiety over France's referendum on the Maastricht Treaty contrived to strain Europe's weak currencies. Sellers succeeded in driving the lira out of the ERM and obliged devaluation of the peseta. The Belgian franc was hurt by the country's close economic ties to France and the weakness of the French franc.

\section{November 1992: Ireland}

The punt displayed continued weakness in the wake of the September attack, the depreciation of sterling, realignments by Portugal and Spain, and the looming removal of Irish capital controls. 


\section{References}

Agenor, Pierre-Richard, Jagdeep S. Bhandari and Robert P. Flood (1992), "Speculative Attacks and Models of Balance of Payments Crises," Staff Papers 39, pp.357-394.

Bank for International Settlements (1993), 63rd Annual Report, Basle: BIS.

Bensaid, Bernard and Olivier Jeanne (1994) "The Instability of Fixed Exchange Rate Systems When Raising the Nominal Interest Rate is Costly," unpublished manuscript, ENPC.

Blackburn, Keith and Martin Sola (1993), "Speculative Currency Attacks and Balance of Payments Crises," Joumal of Economic Surveys 7, pp.119-144.

Blanchard, Olivier and Mark Watson (1982), "Bubbles, Rational Expectations and Financial Markets," National Bureau of Economic Research Working Paper no. 945.

Blanco, Herminio and Peter M. Garber (1986), "Recurrent Devaluation and Speculative Attacks on the Mexican Peso, " Joumal of Political Economy 94, pp.148-166.

Claessens, Stijn (1991), "Balance of Payments Crises in an Optimal Portfolio Model," European Economic Review 35, pp.81-101.

Commission of the European Communities, Directorate-General for Economic and Financial Affairs (1993), "The ERM in 1992," European Economy 54, pp.141-157.

Committee of Governors of the Central Banks of the Member States of the European Economic Community (1993a), Annual Report 1992, Basle: Committee of Governors.

Committee of Governors of the Central Banks of the Member States of the European Economic Community (1993b), "The Implications and Lessons to be Drawn from the Recent Exchange Rate Crisis: Report of the Committee of Governors," processed, 21 April.

Cooper, Richard (1971), "Exchange Rate Devaluation in Developing Countries," Princeton Essays in International Finance no. 86, International Finance Section, Department of Economics, Princeton University.

Cumby, Robert E. and Sweder van Wijnbergen (1989), "Financial Policy and Speculative Runs with a Crawling Peg: Argentina 1979-1981," Joumal of International Economics 27, pp.111-127.

Dellas, Harris and Alan C. Stockman (1993), "Self-Fulfilling Expectations, Speculative Attacks and Capital Controls," Journal of Money, Credit and Banking 25, pp.721-730. 
Dominguez, Kathryn M. and Peter B. Kenen (1992), "Intramarginal Intervention in the EMS and the Target-Zone Model of Exchange Rate Behavior, "European Economic Review 36, pp. 1523-1532.

Dombusch, Rudiger (1993), "Comment," Brookings Papers on Economic Activity 1, pp.130-136.

Edwards, Sebastian (1989), Real Exchange Rates. Devaluation and Adjustment: Exchange Rate Policy in Developing Countries, Cambridge, Mass.: MTT Press.

Edwards, Sebastian (1993), "Devaluation Controversies in the Developing Countries," in Michael D. Bordo and Barry Eichengreen (eds), A Retrospective on the Bretton Woods System, Chicago: University of Chicago Press, pp.405-455.

Eichengreen, Barry (1991), "Relaxing the External Constraint: Europe in the 1930s," in George Alogoskoufis, Lucas Papademos and Richard Portes (eds), Extemal Constraints on Macroeconomic Policy: The European Experience, Cambridge: Cambridge University Press, pp.75-117.

Eichengreen, Barry, Andrew K. Rose and Charles Wyplosz (1994) "Is There a Safe Passage to EMU? Evidence from the Markets, " unpublished manuscript, University of Califomia at Berkeley and INSEAD.

Eichengreen, Barry and Charles Wyplosz (1993), "The Unstable EMS," Brookings Papers on Economic Activity 1, pp.51-143.

Flood, Robert and Peter Garber (1984a), "Collapsing Exchange-Rate Regimes: Some Linear Examples," Journal of International Economics 17, pp.1-13.

Flood, Robert and Peter Garber (1984b), "Gold Monetization and Gold Discipline," Loumal of Political Economy 92, pp.90-107.

Flood, Robert and Robert Hodrick (1986), "Real Aspects of Exchange Rate Regime Choice with Collapsing Fixed Rates," Joumal of International Economics 21, pp.215-232.

Frankel, Jeffrey A. (1994), "Exchange Rate Policy," in Martin Feldstein (ed.), American Economic Policy in the 1980s, Chicago: University of Chicago Press, pp.293-341.

Funibashi, Yoichi (1988), Managing the Dollar, Washington, D.C.: Institute for International Economics.

Giavazzi, Francesco and Alberto Giovannini (1989), Managing Exchange Rate Flexibility: The European Monetary System, Cambridge: MTT Press. 
Girton, Lance and Don Roper (1977), "A Monetary Model of Exchange Market Pressure Applied to Postwar Canadian Experience," American Economic Review 67, pp.537-548.

Goldberg, Linda (1993), "Predicting Exchange Rate Crises: Mexico Revisited, " Joumal of International Economics (forthcoming).

Goldstein, Morris, David Folkerts-Landau, Peter Garber, Liliana Rojas-Suarez and Michael Spencer (1993), International Capital Markets. Part 1. Exchange Rate Management and International Capital Flows, Washington D.C.: International Monetary Fund.

Goldstein, Morris and Michael Mussa (1994), "The Integration of World Capital Markets," in Federal Reserve Bank of Kansas City, Changing Capital Markets: Implications for Monetary Policy, Kansas City: Federal Reserve Bank of Kansas City, pp.245-314.

Grilli, Vittorio (1986) "Buying and Selling Attacks on Fixed Exchange Rate Systems," Joumal of Intemational Economics 20, pp. 143-156.

Grilli, Vittorio (1990), "Managing Exchange Rate Crises: Evidence from the 1980s," Loumal of International Money and Finance 9, pp.135-182.

Gros, Daniel (1992), "Capital Controls and Foreign Exchange Market Crises in the EMS," European Economic Review 36, pp.1533-1544.

Group of Ten (1993), International Capital Movements and Foreign Exchange Markets [Dini Report], Washington, D.C.: Group of Ten.

Harberger, A. and S. Edwards (1982), "Lessons of Experience Under Fixed Exchange Rates," in M. Gersovitz et al. (eds), The Theory and Experience of Economic Development, London: Allen \& Unwin.

Kamin, Steve (1988), "Devaluation, External Balance and Macroeconomic Performance: A Look at the Numbers," Princeton Essays in International Finance no. 62, International Finance Section, Department of Economics, Princeton University.

Klein, Michael W. and Nancy P. Marion (1994), "Explaining the Duration of ExchangeRate Pegs," National Bureau of Economic Research Working Paper no. 4651.

Krugman, Paul (1979), "A Model of Balance of Payments Crises," Joumal of Money Credit and Banking 11, pp.311-325.

Meese, Richard and Kenneth Rogoff (1983), "Empirical Exchange Rate Models of the Seventies: Do They Fit Out of Sample?" Journal of International Economics 14, pp.3-24. 
Monetary Committee of the European Community (1993), "Lessons to be Drawn from the Disturbances on the Foreign Exchange Markets," processed, 13 April.

Obstfeld, Maurice (1984), "Balance of Payments Crises and Devaluation," Loumal of Money. Credit and Banking 16, pp.208-217.

Obstfeld, Maurice (1986), "Rational and Self-Fulfilling Balance-of-Payments Crises," American Economic Review LXXVI, pp.72-81.

Obstfeld, Maurice (1994), "The Logic of Currency Crises," National Bureau of Economic Research Working Paper No. 4640.

Ozkan, F. Gulcin and Alan Sutherland (1993), "A Model of the ERM Crisis," unpublished manuscript, University of York.

Portes, Richard (1993), "EMS and EMU After the Fall," The World Economy 19, pp.116.

Rose, Andrew and Lars Svensson (1994), "European Exchange Rate Credibility Before the Fall," European Economic Review **, pp. ${ }^{* *-* *}$.

Salant, Stephen W. (1983), "The Vulnerability of Price Stabilization Schemes to Speculative Attack," Journal of Political Economy 91, pp.1-38.

Salant, Stephen W. and Dale W. Henderson (1978), "Market Anticipation of Government Policy and the Price of Gold," Joumal of Political Economy 86, pp.627-648.

West, Kenneth (1987), "A Standard Monetary Model and the Variability of the Deutschemark-Dollar Exchange Rates," Journal of International Economics 23, pp.57-76.

Williamson, John (1993), "EMS and EMU After the Fall: A Comment," The World Economy 16, pp.377-380.

Willman, Alpo (1988), "The Collapse of the Fixed Exchange Rate Regime with Sticky Wages and Imperfect Substitutability Between Domestic and Foreign Bonds, "European Economic Review 32, pp.1817-1838.

Woo, Wing T. (1985), "The Monetary Approach to Exchange Rate Determination Under Rational Expectations," Joumal of International Economics 18, pp.1-16.

Wyplosz, Charles (1986), "Capital Controls and Balance of Payments Crises," Joumal of International Money and Finance 5, pp.167-179. 


\section{Endnotes}

1. These models derived from previous analyses of attacks on commodity-price stabilization schemes (Salant and Henderson 1978, Salant 1983). The subsequent literature developing these models is reviewed by Agenor, Bhandari and Flood (1992) and Blackburn and Sola (1993). We are indebted to these reviews for our own survey of the literature.

2. For discussion of this point see Flood and Hodrick (1986).

3. We do this in more detail in the appendix to the paper.

4. It is the supply of domestic assets following the attack rather than the pre-attack supply that determines the shadow exchange rate; the two differ because speculators swap a portion of their domestic asset holdings for foreign exchange when undertaking the attack that exhausts the central bank's remaining reserves and forces the transition to floating (see Grilli, 1986).

5. See also Flood and Hodrick (1986) and Wyplosz (1986).

6. Dellas and Stockman (1993) showed that the same result can obtain if an attack induces the authorities to impose capital controls on a regime of previously free international capital mobility.

7. George Soros, International Investment Research (July 5, 1994), p.2. We thank Luis Freitas for bringing this statement to our attention.

8. See also Gros (1992) and Obstfeld (1994).

9. This contrast is subject to qualification by the problem of observational equivalence noted in the introduction. This paragraph refers to simple variants of first-generation models; more complicated variants of the first-generation model can suggest a deterministic shift in post-attack policy in a more expansionary direction.

10. A recent study which re-examines this episode is Goldberg (1993).

11. This is an appropriate juncture at which to flag a point anticipated in the introduction. Any empirical model of crises requires a model of the asset demands from which the exchange rate is derived. Most investigators, like Blanco and Garber, use standard money demand functions and assumptions akin to purchasing power parity. That such models fail to adequately track exchange rate movements is well known; the problem is equally debilitating in the present context where it is reserves rather than the exchange rate that are permitted to move.

12. In addition, an increase in openness significantly reduces the probability of ending a peg, while higher trade concentration increases the probability that a peg will end. These findings are consistent with the optimum-currency-area literature, in which it is suggested that more open, less trade-diversified economies have a stronger desire to peg. 
13. Other studies which follow this approach include Cooper (1971), Harberger and Edwards (1982), Kamin (1988) and Eichengreen (1991).

14. Once we construct a sample of "events," it becomes possible to contrast their characteristics with those of successful attacks in which previously pegged exchange rates were abandoned as a way of gauging the extent of such selectivity bias, as we do below.

15. Robert Flood has pointed out that this problem has an analogy in the literature on bubbles in foreign exchange markets. Bubbles are another instance of multiple equilibria analogous to the second-generation models of speculative attacks on pegged rates, the difference being that the exchange rate is freely determined in the exchange market bubbles literature while it is pegged and reserves are freely determined in the speculative attack literature (or rather, reserves, interest rates and other policy instruments that can be used to defend the rate). Woo (1985) and West (1987) test for bubbles using monetary models of exchange rate determination. Their attempt to identify bubbles using this structural approach is no more convincing than their monetary model. Our less structured analysis can be seen as a counterpart of the nonparametric approach to analyzing bubbles of authors like Blanchard and Watson (1982).

16. We typically add exchange rate changes to a .08 multiple of reserve movements and a seven-fold multiple of interest rate differential movements.

17. Germany was the leading strong-currency country in the latter part of the Bretton Woods period and under the Snake as well as in the European Monetary System. We also computed changes in most of our key macroeconomic variables relative to Germany.

18. This pattern in fact occurred in September 1992. Thus, when we attach a high weight to changes in relative reserves, our index identifies the guilder as one of the currencies that was attacked that month.

19. In future work, we hope to use weekly and daily data on interest rates and exchange rates to identify other possible periods in which speculative crises occurred.

20. For details, see Giavazzi and Giovannini (1989).

21. This may be thought of as a peso problem in second moments.

22. In 1987, for example, the finance ministers of the G-7 countries agreed at the Louvre meeting to establish "reference values" for the dollar and other currencies "around current levels" but refused to reveal the width of the reference range. According to Funibashi (1988), they agreed to a narrow margin of plus or minus $21 / 2$ per cent, after which intervention would be called for on a voluntary basis, and a wider band of plus or minus five per cent, at which point concerted intervention would be obligatory.

23. On the free float of the 1980s, see Frankel (1994). 
24. In particular, we limit our tests below to countries with explicitly declared bilateral bandwidths of no more than $15 \%$.

25. Information on the events listed in Table 1 is provided in the appendix.

26. This pattern becomes even more pronounced when we increase the weight on reserves when constructing our index, as discussed below.

27. The correlation between reserve changes and exchange rate changes is -0.13 and between reserve changes and interest rate changes is -0.24 . The positive correlation between exchange rate and interest rate changes is a relatively low 0.04 .

28. Our list of events also changes in a sensible way when we alter the weights on the three components of our index.

29. It would be interesting, but beyond the scope of this paper, to analyze the crises which occur closely together.

30. Crises are defined as observations where our measure of speculative pressure lies at least one and a half standard deviations above its sample mean; this threshold is used to create smoothness in the histograms. However, most of the statistical results (e.g., in Table 2) use a three standard deviation threshold. A sensitivity analysis shows that this cutoff point is arbitrary but not especially important.

31. All four histograms scaled so as to be directly compared one another.

32. Unlike the other variables, which are calculated for the 12 months preceding the event, the real exchange rate is considered in the month immediately preceding the event since it is constructed relative to its 1985 base.

33. The differences in reserve behavior between events and non-events is more pronounced for the ERM cases. This is not surprising, since as we noted above the ERM requires mandatory intervention at the margin not only by the country in question but by the strong currency country, typically Germany, our reference country against which the change in reserves is measured.

34. Sample size varies by variable due to missing observations and different sample spans.

35. Only the difference is credit growth goes in the wrong direction.

36. The weak results on interest rate differentials may indicate that there is considerable measurement error inherent in the procedure which we use to identify speculative attacks, an issue to which we return later. However, we frequently find similar results for actual realignments and exchange rate regime switches. 
37. An important limitation of these results (which we plan to rectify in future work) is that they are based on univariate analysis. An absence of differences in the distributions of monetary and fiscal variables in attack and non-attack cases when such variables are considered separately may disguise interactions among them that differ across categories.

38. We are grateful to Torsten Persson and Victor Rios-Ruell for leading us to this thought. 